\title{
Potential of Modified Multiwalled Carbon Nanotubes with 1-(2-Pyridylazo)-2-naphtol as a New Solid Sorbent for the Preconcentration of Trace Amounts of Cobalt(II) Ion
}

\author{
Daryoush AfZaLi ${ }^{\dagger}$ and Ali Mostafavi \\ Department of Chemistry, Shahid Bahonar University of Kerman, Kerman, Iran
}

\begin{abstract}
The present paper reports on the application of modified multiwalled carbon nanotubes (MMWCNTs) as a new, easily prepared and stable solid sorbent for the preconcentration of trace $\mathrm{Co}(\mathrm{II})$ in aqueous solution. Multiwalled carbon nanotubes (MWCNTs) were oxidized with concentrated $\mathrm{HNO}_{3}$ and modified with 1-(2-pyridylazo)-2-naphtol (PAN), and were then used as a solid phase for the preconcentration of $\mathrm{Co}(\mathrm{II})$. Factors influencing the sorption and desorption of $\mathrm{Co}$ (II) were investigated. Elution was carried out with $0.5 \mathrm{~mol} \mathrm{~L}{ }^{-1} \mathrm{HNO}_{3}$. The amount of eluted $\mathrm{Co}$ (II) was measured using flame atomic absorption spectrometry. The effects of the experimental parameters, including the sample $\mathrm{pH}$, sample flow rate, eluent flow rate and eluent concentration, were investigated. The effect of coexisting ions showed no interference from most ions tested. The proposed method permitted a large enrichment factor (about 300). The precision of the method was $1.63 \%$ (for eight replicate determination of $0.5 \mu \mathrm{g} \mathrm{mL} \mathrm{m}^{-1}$ of $\mathrm{Co}$ (II)) and the limit of detection was 0.55 $\mathrm{ng} \mathrm{mL} \mathrm{m}^{-1}$. The method was applied to the determination of $\mathrm{Co}(\mathrm{II})$ in water, biological and standard samples.
\end{abstract}

(Received September 26, 2007; Accepted March 6, 2008; Published September 10, 2008)

In recent years, great attention has been paid to the application of nano-structure materials, especially carbon nanotubes (CNTs). In particular, there have been an increasing number of applications of CNTs in several fields of chemical analysis. ${ }^{1}$ CNTs may be considered as sheets of graphite that are rolled into a tube and classified as single-walled carbon nanotubes (SWCNTs) and multiwalled carbon nanotubes (MWCNTs), depending on of carbon atom layers in the wall of the nanotubes. $^{2}$ Because of their special electronic, metallic and structural characteristics as well as the unique tubular structures of nano diameter and large length/diameter ratio, ${ }^{3}$ CNTs have been exploited in analytical chemistry and other fields, such as gas sensors, ${ }^{4,5}$ voltammetry, ${ }^{6}$ stripping voltammetry, ${ }^{7,8}$ biosensors $^{9}$ and chromatographic applications. ${ }^{10}$ The highly developed hydrophobic surface of CNTs exhibits strong sorption properties toward various compounds, and therefore CNTs may be used for the separation and preconcentration of trace analytes. ${ }^{11} \quad$ MWCNTs have also been used for the preconcentration of trace amounts of organic materials ${ }^{12-14}$ and the removal of heavy metal cations from water. ${ }^{15,16}$

Cobalt is an important trace element in nature, and depending on its concentration, can be either essential or toxic for many biological systems. ${ }^{17}$ It is clear that the determination of trace amounts of cobalt in biological and environmental samples plays an important role in the field of environmental surveillance, food control, medicine and toxicology. Flame atomic absorption spectrometry (FAAS) is a simple and easily available technique for the determination of cobalt in real samples. However, its main problem is low sensitivity for trace cobalt at the $\mathrm{ng} \mathrm{mL}^{-1}$ level. This limitation can be overcome by the use of preconcentration. For this purpose, various

$\dagger$ To whom correspondence should be addressed.

E-mail: daryoush_afzali@yahoo.com preconcentration/separation methods, including coprecipitation, ${ }^{18}$ liquid-liquid extraction, ${ }^{19}$ ion exchange ${ }^{20}$ and chelating sorbent ${ }^{21}$ have been used. Solid phase extraction (SPE) has several advantages over other separation techniques in view of (i) high recovery, (ii) short analysis time, (iii) high enrichment factor, (iv) low consumption of organic solvents, (v) reusability of an adsorbent, (vi) absence of emulsion, (vii) ease of automation, and (viii) being environmental friendly. Until recently, several kinds of SPE sorbents, such as C-18 bonded silica, ${ }^{22}$ polymeric supports, ${ }^{23}$ chelating resin, ${ }^{24}$ functionalized silica, ${ }^{25}$ functionalized cellulose, ${ }^{26}$ activated oxide, ${ }^{27}$ activated carbon, ${ }^{28}$ XAD-4 Amberlite resin, ${ }^{29}$ modified Analcime zeolite ${ }^{30}$ and glycerol-silica gel, ${ }^{31}$ have been used for the preconcentration of trace $\mathrm{Co}(\mathrm{II})$. However, there were no references to the application of MMWCNTs for the preconcentration of trace Co(II). The goal of this study is to modify MWCNTs by 1-(2pyridylazo)-2-naphtol (PAN). Further, the performances of MMWCNTs are tested as a new sorbent for the preconcentration of trace $\mathrm{Co}(\mathrm{II})$. A procedure is proposed for the determination of trace $\mathrm{Co}$ (II) by FAAS after separation and preconcentration are carried out in a glass column filled with MMWCNTs. Applications of the proposed method for the analysis of different samples are also described.

\section{Experimental}

\section{Reagents}

Highest-grade commercially available reagents were used without further purification. A Co(II) stock solution 1000 $\mathrm{mg} \mathrm{L}^{-1}$ was prepared by dissolving $0.4940 \mathrm{~g}$ of $\mathrm{Co}\left(\mathrm{NO}_{3}\right)_{2} \cdot 6 \mathrm{H}_{2} \mathrm{O}$ (Fluka, Switzerland) into a $100 \mathrm{~mL}$ volumetric flask and diluting to the mark with distilled water, then standardized by known methods. ${ }^{32}$ Standard solutions were prepared daily from a stock 
solution by serial dilution water. A $0.5 \%$ solution of PAN (Merck, Germany) was prepared by dissolving it in ethanol. Three buffer solutions were prepared: (1) from $0.5 \mathrm{~mol} \mathrm{~L}^{-1}$ acetic acid and $0.5 \mathrm{~mol} \mathrm{~L}^{-1}$ sodium acetate for $\mathrm{pH} 3-6$, (2) from a $0.1 \mathrm{~mol} \mathrm{~L}^{-1}$ potassium dihydrogen-phosphate solution and a $0.1 \mathrm{~mol} \mathrm{~L}^{-1}$ disodium hydrogen-phosphate solution for $\mathrm{pH} 6-8$ and (3) from $0.1 \mathrm{~mol} \mathrm{~L}^{-1}$ ammonia and $0.5 \mathrm{~mol} \mathrm{~L}^{-1}$ ammonium acetate for $\mathrm{pH} 8-11$. Solutions of alkali metal salts (1\%) and various metal salts $(0.1 \%)$ were used to study the interference of ions. MWCNTs with an average diameter of $10-30 \mathrm{~nm}$, length of $5-15 \mu \mathrm{m}$ and surface of $60-300 \mathrm{~m}^{2} \mathrm{~g}^{-1}$ were obtained from Sun Nanotech, China. Raw MWCNTs were heated at $300^{\circ} \mathrm{C}$ for $40 \mathrm{~min}$ to remove amorphous carbon. Prior to use, MWCNTs were oxidized with concentrated $\mathrm{HNO}_{3}$ according to the literature, in order to create binding sites onto the surface of MWCNTs. ${ }^{11,33}$ The treatment was carried out by the dispersion of $25 \mathrm{~mL}$ of concentrated $\mathrm{HNO}_{3}$ to $1 \mathrm{~g}$ of MWCNTs, and then refluxing for $6 \mathrm{~h}$ at $100^{\circ} \mathrm{C}$. Afterward, the MWCNTs were washed with distilled water until removing any excess nitric acid (neutral $\mathrm{pH}$ of solution); then, $10 \mathrm{~mL}$ of a $0.5 \%$ solution of PAN was added to the MWCNTs, and refluxed for $3 \mathrm{~h}$ at $75^{\circ} \mathrm{C}$, producing modified multiwalled carbon nanotubes (MMWCNTs), which were dried at $100^{\circ} \mathrm{C}$ and stored until use. The maximum capacity of MWCNTs was $1.12 \mathrm{mg}$ of PAN per gram of MWCNTs.

\section{Apparatus}

A Varian Model SpectrAA 220 (Mulgrave, Vic, Australia) atomic absorption spectrometer was used for measuring $\mathrm{Co}$ (II) in an air-acetylene flame. The operating conditions were as follows: wavelength, $240.7 \mathrm{~nm}$; lamp current, $7 \mathrm{~mA}$; slit width, $0.2 \mathrm{~nm}$. The flow rates of air and acetylene were set as recommended by the manufacturer. The $\mathrm{pH}$ measurement was carried out using a Metrohm pH meter (Model 713) with a combined $\mathrm{pH}$ glass electrode calibrated against two standard buffer solutions at $\mathrm{pH} 4.0$ and 7.0. The column dimensions were $10 \times 80 \mathrm{~mm}$ with a sintered glass plate located at the bottom of the column.

\section{Recommended procedure}

A glass column packed with $0.04 \mathrm{~g}$ MMWCNTs sorbent (height of packing being about $15 \mathrm{~mm}$ ) was used as the operational column. Initially for column conditioning, distilled water $(5 \mathrm{~mL})$ was passed through the column. Before sample loading, the column had to be preconditioned by passing $5 \mathrm{~mL}$ of a buffer solution $(\mathrm{pH} \sim 7)$ through it. Then, an aliquot of $\mathrm{Co}$ (II) solution was passed through the column. The adsorbed $\mathrm{Co}$ (II) was eluted with $3.0 \mathrm{~mL}$ of $0.5 \mathrm{~mol} \mathrm{~L}^{-1} \mathrm{HNO}_{3}$ at an elution rate of $1 \mathrm{ml} \mathrm{L}^{-1}$. Then, the eluted solution was aspirated directly into the flame of AAS and compared with a blank prepared in the same manner, but without the addition of $\mathrm{Co}(\mathrm{II})$.

\section{Procedure for the pepperbush NIES sample}

A $100 \mathrm{mg}$ amount of pepperbush reference material (NIES No. 1) sample was decomposed with $5 \mathrm{~mL}$ of a mixture containing concentrated $\mathrm{HNO}_{3}$ and $\mathrm{HClO}_{4}$ (1:1 ratio); and the solution was evaporated to dryness. This process was repeated twice, and $10 \mathrm{~mL}$ of distilled water was added to the residue. The suspension was filtered through a filter paper circle blue, ribbon and a preconcentration procedure was applied to the final solution.

\section{Procedures for natural water}

Before the analysis of water samples, the samples were filtered through a cellulose membrane filter of $4.5 \mu \mathrm{m}$ pore size. For preconcentration, the $\mathrm{pH}$ of $120 \mathrm{~mL}$ of the sample was adjusted to 7 with a buffer solution, and the preconcentration procedure was applied to the final solution.

\section{Procedure for biological samples}

A $1.0 \mathrm{~g}$ portion of dried tomato leaves was decomposed with a $10 \mathrm{~mL}$ mixture of concentrated $\mathrm{HClO}_{4}$ and $\mathrm{H}_{2} \mathrm{SO}_{4}$ (2:1 ratio) by heating, and solution was evaporated to dryness. This process was repeated twice, and $20 \mathrm{~mL}$ of distilled water was added to the residue. The suspension was filtered through blue band filter paper, and the preconcentration procedure was applied to the final solution.

A $0.70 \mathrm{~g}$ carrot sample was decomposed with a $15 \mathrm{~mL}$ mixture of concentrated $\mathrm{HClO}_{4}$ and $\mathrm{H}_{2} \mathrm{SO}_{4}$ (1:1 ratio) by heating, and solution was evaporated to dryness. This process was repeated twice, and $15 \mathrm{~mL}$ of distilled water was added to the residue. The suspension was filtered through blue band filter paper, and the preconcentration procedure was applied to the final solution.

\section{Results and Discussion}

Preliminary experiments showed that MWCNTs have a low tendency for the retention of $\mathrm{Co}$ (II) adsorption (65.6\%). Recent work $^{12-14}$ indicated that the MWCNTs can adsorb organic material, and therefore, since PAN is a good reagent complexing with $\mathrm{Co}(\mathrm{II})$, it was added to MWCNTs. Modified multiwalled carbon nanotubes (MMWCNTs) were capable of retaining $\mathrm{Co}$ (II) in the sample solution (99.7 adsorption of Co(II) when the test solution contained $1.5 \mu \mathrm{g}$ of $\mathrm{Co}(\mathrm{II})$ in $10 \mathrm{~mL}$ water). Thus, the adsorption of PAN on the surface of MWCNTs had an effective role in the sorption of $\mathrm{Co}$ (II). In order to achieve the best performance from this system, different parameters were optimized. The $\mathrm{pH}$ of the sample, type and concentration of the eluent, the effects of the sample and eluent flow rates on the extraction efficiency, the effect of foreign ions, the effect of the sample volume and the maximum capacity of the sorbent for Co(II) recovery, were studied.

\section{Effect of the sample $p H$}

The percent sorption of Cobalt ion $\left(3.0 \mathrm{~mL}\right.$ of $\left.0.5 \mu \mathrm{g} \mathrm{mL} \mathrm{g}^{-1}\right)$ on the sorbent surface $(0.04 \mathrm{~g})$ as a function of the $\mathrm{pH}$ of the sample solution was examined in the range of $2-11.5$. The $\mathrm{pH}$ was adjusted by using a buffer solution. As can be seen from Fig. 1, the percent sorption of $\mathrm{Co}(\mathrm{II})$ depends on the $\mathrm{pH}$ of the sample solution, and is about $97 \%$ in the $\mathrm{pH}$ range $5-8.5$. When $\mathrm{pH}<5$, hydronium could compete with $\mathrm{Co}$ (II) with regard to adsorption on the MMWCNTs. On the other hand, the transformation of $\mathrm{Co}(\mathrm{II})$ to $\mathrm{Co}(\mathrm{III})$ is responsible for a decrease in the efficiency of $\mathrm{Co}$ (II) sorption at $\mathrm{pH}$ values greater than 8.5. Therefore, the $\mathrm{pH}$ value of the sample solution is kept within the range $5-8.5$. A pH of 7 in the middle of the $\mathrm{pH}$ range was considered as being the optimum value to avoid an abrupt change in adsorption, which may occur due to minor changes in the $\mathrm{pH}$.

\section{Effect of the sample flow rate}

The flow rate of the sample solution is a measure of the contact time between the sample solution and the sorbent. The flow rate was adjusted simply by connecting the adsorbing column to a flask, which had a controllable vacuum. Aliquots of $3.0 \mathrm{~mL}$ of $0.5 \mu \mathrm{g} \mathrm{mL} \mathrm{m}^{-1} \mathrm{Co}(\mathrm{II})$ solutions at $\mathrm{pH} 7$ were introduced into a packed column containing $0.04 \mathrm{~g}$ of the sorbent. The results showed that the flow-rate variation in the range of $0.5-5 \mathrm{~mL} \mathrm{~min}^{-1}$ did not have a significant effect on the 


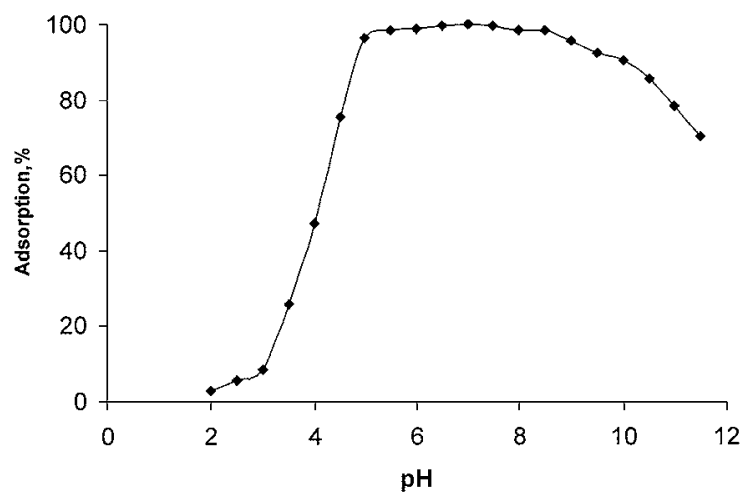

Fig. 1 Effect of the $\mathrm{pH}$ of the sample solution on the percent sorption of $\mathrm{Co}(\mathrm{II})$.

sorption of the cobalt ion. It was found that the adsorption of Co(II) on MMWCNTs is relatively rapid. In order to achieve good precision, a flow rate of $2 \mathrm{~mL} \mathrm{~min}^{-1}$ was chosen for further studies. Furthermore, the chosen sample flow rate still provided more than $99 \%$ adsorption of Co(II).

\section{Selection of desorption}

A series of selected eluents, such as $\mathrm{HCl}, \mathrm{HNO}_{3}, \mathrm{H}_{2} \mathrm{SO}_{4}$, sodium thiosulfate, sodium citrate, and sodium oxalate, were used in order to find the best eluent for the desorption of cobalt ion from the sorbent surface. An aliquot of $0.5 \mu \mathrm{g} \mathrm{mL} \mathrm{m}^{-1} \mathrm{Co}$ (II) solution was passed at a flow rate of $2 \mathrm{~mL} \mathrm{~min}^{-1}$ through a series of columns containing $0.04 \mathrm{~g}$ of sorbent at $\mathrm{pH} 7$. The adsorbed cobalt ion was eluted by passing through the above-mentioned selected eluents by means of $3.0 \mathrm{~mL}$ of $0.5 \mathrm{~mol} \mathrm{~L}^{-1}$. The amount of cobalt ion hence extracted into the liquid phase by each eluent was measured using FAAS, and the percent recoveries of $\mathrm{Co}$ (II) were calculated in each case. The results showed that the best recovery was achieved when $\mathrm{HNO}_{3}$ was used as the eluent. For a sodium thiosulfate, sodium citrate and sodium oxalate solution, the $\mathrm{pH}$ of the eluent affected the elution and recovery of $\mathrm{Co}(\mathrm{II})$. To find the optimum $\mathrm{pH}$ value of these eluent solutions for desorbing $1.5 \mu \mathrm{g}$ of $\mathrm{Co}(\mathrm{II})$, already adsorbed on $0.04 \mathrm{~g}$ of sorbent, a series of solutions with different $\mathrm{pH}$ values were tested. The $\mathrm{pH}$ was adjusted by using either nitric acid or sodium hydroxide solutions. The percent of recoveries of $\mathrm{Co}$ (II) at $\mathrm{pH}<5.5$ was less than $93 \%$, and the maximum was at a $\mathrm{pH}$ of 2.0 , with a percent of recovery of $94 \%$. Thus, it could be concluded that at low $\mathrm{pH}$ values, the hydronium ion could be compete with $\mathrm{Co}$ (II) for being adsorbed on the sorbent and thus cause the removal of $\mathrm{Co}$ (II) from the sorbent. Therefore, the $\mathrm{HNO}_{3}, \mathrm{HCl}$ and $\mathrm{H}_{2} \mathrm{SO}_{4}$ solution was tested as an eluent. It was observed that a quantitative recovery $(>98 \%)$ of $\mathrm{Co}$ (II) was desorbed using $0.5 \mathrm{~mol} \mathrm{~L}^{-1}$ of $\mathrm{HNO}_{3}$. The effect of the concentration of $\mathrm{HNO}_{3}$ on the recovery of $\mathrm{Co}(\mathrm{II})$ was studied; the results are shown in Fig. 2.

\section{Effect of the flow rate of a desorption solution}

The effect of the flow rate of the eluent solution on the desorption of $1.5 \mu \mathrm{g} \mathrm{Co}(\mathrm{II})$, from the sorbent surface $(0.04 \mathrm{~g})$ was studied in the range of $0.5-5 \mathrm{~mL} \mathrm{~min}^{-1}$. The cobalt ion was completely desorbed at an eluent flow rate of less than $3 \mathrm{~mL} \mathrm{~min}^{-1}$, for effective and quantitative elution. However, a flow rate of $1 \mathrm{~mL} \mathrm{~min}{ }^{-1}$ was chosen for future studies.

\section{Breakthrough volume}

When solutions containing $1.5 \mu \mathrm{g}$ of cobalt in $100,200,500$,

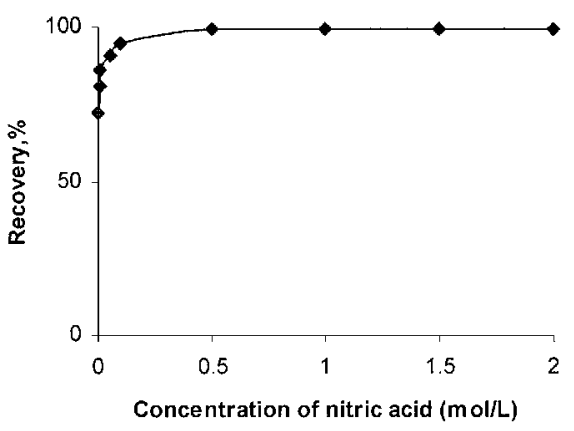

Fig. 2 Effect of the concentration of $\mathrm{HNO}_{3}$ on the recovery of Co(II).

Table 1 Effect of foreign ions on percent recovery of $\mathrm{Co}$ (II) $\left(0.5 \mu \mathrm{g} \mathrm{mL}^{-1}\right)$

\begin{tabular}{lrrlrr}
\hline & $\begin{array}{c}\text { Conc./ } \\
\mu \mathrm{g} \mathrm{mL}{ }^{-1}\end{array}$ & Rec., $\%$ & & $\begin{array}{c}\text { Conc./ } \\
\mu \mathrm{g} \mathrm{mL} \mathrm{mL}^{-1}\end{array}$ & $\mathrm{Rec} . \%$ \\
\hline $\mathrm{Na}^{+}$ & 3000 & 99.1 & $\mathrm{Zn}^{2+}$ & 50 & 98.4 \\
$\mathrm{~K}^{+}$ & 2000 & 98.7 & $\mathrm{Cu}^{2+}$ & 50 & 101.1 \\
$\mathrm{Ca}^{2+}$ & 300 & 101.6 & $\mathrm{Ni}^{2+}$ & 30 & 97.3 \\
$\mathrm{Mg}^{2+}$ & 400 & 97.3 & $\mathrm{Ag}^{+}$ & 40 & 97.1 \\
$\mathrm{Fe}^{3+}$ & 100 & 100.2 & $\mathrm{Hg}^{2+}$ & 100 & 99.4 \\
$\mathrm{Al}^{3+}$ & 60 & 97.7 & $\mathrm{PO}_{4}{ }^{3-}$ & 700 & 99.8 \\
$\mathrm{~Pb}^{2+}$ & 100 & 98.1 & $\mathrm{NO}_{3}{ }^{-}$ & 1000 & 99.3 \\
$\mathrm{Mn}^{2+}$ & 30 & 100.7 & $\mathrm{SO}_{4}{ }^{2-}$ & 1000 & 99.1 \\
$\mathrm{Cd}^{2+}$ & 60 & 96.8 & $\mathrm{Cl}^{-}$ & 4000 & 98.7 \\
\hline
\end{tabular}

700 and $900 \mathrm{~mL}$ of water were passed through the columns, the $\mathrm{Co}$ (II) was quantitatively retained in all cases. We conclude that the breakthrough volume of the method under optimum conditions should be greater than $900 \mathrm{~mL}$. The results showed that the necessary minimum concentration was $1.6 \mathrm{ng} \mathrm{mL}^{-1}$. Consequently, by considering the final elution volume of $3.0 \mathrm{~mL}$ of $0.5 \mathrm{~mol} \mathrm{~L}^{-1} \mathrm{HNO}_{3}$, and a breakthrough volume of $900 \mathrm{~mL}$, a preconcentration factor of 300 was easily achievable.

\section{Evaluation of sorbent property}

The sorption capacity of MMWCNTs was determined by passing $30 \mathrm{~mL}$ of $100 \mu \mathrm{g} \mathrm{mL}-1$ Co(II), followed by the determination of retained $\mathrm{Co}$ (II) using FAAS. The maximum capacity of the sorbent was $750 \mu \mathrm{g}$ of $\mathrm{Co}(\mathrm{II})$ per gram of sorbent. The MMWCNTs sorbent was subjected to several loadings with the sample solution and subsequent elution. It was found that the adsorption properties of the adsorbent remained constant after 30 cycles of sorption and desorption.

\section{Interferences}

The interferences of coexisting ions in binary mixtures of $\mathrm{Co}$ (II) with foreign ions were studied on the percent recovery of cobalt $\left(0.5 \mu \mathrm{g} \mathrm{mL}^{-1}\right)$. After introducing the binary solution into a column, the adsorbed cobalt ion was eluted by a $0.5 \mathrm{~mol} \mathrm{~L}^{-1}$ $\mathrm{HNO}_{3}$ solution. The content of cobalt ions in effluents was determined using FAAS, and the recoveries were calculated. The results, summarized in Table 1, clearly indicate that most of the tested ions do not interfere with the determination of cobalt. The tolerance limit was set as the amount of foreign ions required to cause a $\pm 4 \%$ error. 
Table 2 Result analysis of a pepperbush standard reference material (NIES No. 1)

\begin{tabular}{ccc}
\hline Sample & Certified value $/ \mu \mathrm{gg}^{-1}$ & Our value/ $\mu \mathrm{g} \mathrm{g}^{-1}$ \\
\hline NIES, No. 1 Pepperbush & $23.0 \pm 3$ & $22.4 \pm 0.8$ \\
\hline
\end{tabular}

Composition (\% or $\mu \mathrm{g} \mathrm{g}^{-1}$ ): K, $1.51 \pm 0.06 ; \mathrm{Mn}, 0.203 \pm 0.17$; Ca, 1.38 $\pm 0.07 ; \mathrm{Mg}, 0.408 \pm 0.020 \% ; \mathrm{Ni}, 8.7 \pm 0.6 ; \mathrm{Cu}, 12 \pm 1 ; \mathrm{Cs}, 1.2 ; \mathrm{Tl}$, $0.13 ; \mathrm{Fe}, 205 \pm 17 ; \mathrm{Co}, 23.0 \pm 3 ; \mathrm{Pb}, 5.5 \pm 0.8 ; \mathrm{P}, 1100 ; \mathrm{Cr}, 1.3 ; \mathrm{Zn}, 340$ $\pm 20 ; \mathrm{Ba}, 165 \pm 10 ; \mathrm{Sr}, 36 \pm 4 ; \mathrm{As}, 2.3 \pm 0.3 ; \mathrm{Rb}, 75 \pm 4 ; \mathrm{Na}, 106 \pm 13$ $\mathrm{Hg}, 0.05 \mu \mathrm{g} \mathrm{g}^{-1}$.

Table 3 Determination of cobalt in water samples; mean \pm standard deviation $(n=3)$

\begin{tabular}{lcrc}
\hline Sample & $\begin{array}{c}\text { Co(II) spiked/ } \\
\text { ng mL } \mathrm{mL}^{-1}\end{array}$ & $\begin{array}{c}\text { Co(II) detected/ } \\
\mathrm{ng} \mathrm{mL}^{-1}\end{array}$ & $\begin{array}{c}\text { Recovery, } \\
\%\end{array}$ \\
\hline Tap water & 0.0 & $3.73( \pm 0.11)$ & - \\
(Kerman) & 5.0 & $8.69( \pm 0.18)$ & 99.5 \\
Tap water & 0.0 & $5.14( \pm 0.14)$ & - \\
(Rayen) & 5.0 & $10.01( \pm 0.20)$ & 98.7 \\
River water & 0.0 & $8.13( \pm 0.16)$ & - \\
(Tahrood, upper) & 10.0 & $18.15( \pm 0.24)$ & 100.1 \\
River water & 0.0 & $11.40( \pm 0.19)$ & - \\
(Tahrood, lower) & 10.0 & $21.25( \pm 0.27)$ & 99.3 \\
\hline
\end{tabular}

\section{Analytical figure of merit}

Analytical figures of merit were evaluated for the determination of cobalt according to the recommended procedure under the optimized conditions. The equation of the calibration curve obtained after analysis of the eluent using FAAS was $A=0.0861 C+0.0058$, with $R^{2}=0.9994$, where $A$ is the absorbance value of the eluent and $C$ is the concentration of $\mathrm{Co}(\mathrm{II})\left(\mu \mathrm{g} \mathrm{mL} \mathrm{m}^{-1}\right)$ after preconcentration in the eluent. The recommended procedure was repeated eight times to find the relative standard deviation in the determination of $0.5 \mu \mathrm{g} \mathrm{mL}$ of $\mathrm{Co}(\mathrm{II})$ ion. RSD was found to be $1.63 \%$. The detection limit was $0.55 \mathrm{ng} \mathrm{mL}^{-1}\left(3 \sigma_{\mathrm{b}} / \mathrm{m}\right)$ in the original solution.

\section{Application of the proposed method}

The developed method was applied to a pepperbush standard reference material (NIES No. 1) for the determination of cobalt. The result, based on the average of five replicates, is tabulated in Table 2. It is clear that the result is in good agreement with the certified value.

The proposed method was used for the determination of cobalt in various water samples from the Kerman region in Iran, and also in tomato leaves and carrots. The results are given in Tables 3 and 4 , and were calculated assuming $100 \%$ recovery.

\section{Conclusion}

The present study demonstrates the preparation and use of a new sorbent based on the modification of MWCNTs as a green sorbent. In this paper, a new method for the application of MWCNTs is proposed. The modification of MWCNTs is simple and low cost, and the reagent remains in MMWCNTs, which allows using the column several times. Using this new sorbent, a simple, rapid, precise, accurate and reliable method is developed for the preconcentration of trace cobalt in real samples. Also, the preconcentration factor of the sorbent is
Table 4 Determination of Co(II) in biological samples; mean \pm standard deviation $(n=3)$

\begin{tabular}{ll}
\hline Sample & Found $/ \mu_{\mathrm{g} \mathrm{g}}{ }^{-1}$ \\
\hline Tomato leaves & $0.63( \pm 0.01)$ \\
Carrot & $0.95( \pm 0.02)$ \\
\hline
\end{tabular}

Table 5 Preconcentration factors of the ligand-immobilized adsorbents for $\mathrm{Co}(\mathrm{II})$

\begin{tabular}{lcc}
\hline \multicolumn{1}{c}{ Ligand } & $\begin{array}{c}\text { Preconcentration } \\
\text { factor }\end{array}$ & Ref. \\
\hline 8-Hydroxyquinoline & 50 & 22 \\
O-Aminophenol & 100 & 24 \\
Zincon & 200 & 29 \\
Zincon & 70 & 30 \\
1-(2-Pyridylazo)-2-naphtol & 300 & Present work \\
\hline
\end{tabular}

found to be higher than the other ligand-immobilized adsorbent (Table 5). The method is economical due to the possibility of multiple uses of the sorbent.

\section{Acknowledgements}

The authors wish to thank students of the Kerman Research Institute and Shahid Dadbin College of Kerman for technical cooperation and Prof. M. Tata for editing the manuscript in terms of grammar.

\section{References}

1. M. Trojanowicz, Trends Anal. Chem., 2006, 25, 480.

2. V. N. Popov, Mater. Sci. Eng. Res., 2004, 43, 61.

3. N. Grobert, Materials Today, 2007, 10, 28.

4. L. M. Dai, P. Soundarrajan, and T. Kim, Pure Appl. Chem., 2002, 74, 1753.

5. J. B. He, C. L. Chen, and J. H. Liu, Sens. Actuators, B, 2004, 99, 1 .

6. J. Li, J. E. Koehne, A. L. Cassell, H. Chen, H. T. Ng, Q. Ye, W. Fan, J. Han, and M. Meyyappan, Electroanalysis, 2005 , $17,15$.

7. B. Z. Zeng and F. Huang, Talanta, 2004, 64, 380.

8. C. H. Yang, Microchim. Acta, 2004, 148, 87.

9. J. Wang, Analyst, 2005, 13, 421.

10. W. Zhang, F. Wan, Y. Xie, J. Gu, J. Wang, K. Yamamoto, and L. Jin, Anal. Chim. Acta, 2004, 512, 207.

11. A. F. Barbosa, M. G. Segatelli, A. C. Pereira, A. S. Santos, L. T. Kubota, P. O. Luccas, and C. R. T. Tarley, Talanta, 2007, 71, 1512 .

12. G. Z. Fang, J. X. He, and S. Wang, J. Chromatogr., A, 2006, 1127, 12.

13. J. Xu. Y. Wang, Y. Xian, L. Jin, and K. Tanaka, Talanta, 2003, 60, 1123.

14. Q. Zhou, W. Wang, and J. Xia, Anal. Chim. Acta, 2006, 559,200

15. C. Lu and H. Chiu, Chem. Eng. Sci., 2006, 61, 1138.

16. Y. H. Li, S. Wang, Z. Luan, J. Ding, C. Xu, and D. Wu, Carbon, 2003, 41, 1057.

17. B. Venugopal and T. D. Luckey, "Metal Toxicity in 
Mammals", 1978, Vol. 2, Plenum Press, New York.

18. V. M. Ivanov, A. I. Busev, and L. I. Smirnova, Anal. Khim., 1970, 25, 1149.

19. H. Eskandari, H. G. Ghaziaskar, and A. A. Ensafi, Anal. Sci., 2001, 17, 327.

20. J. Korkisch and D. Dimitriads, Talanta, 1973, 20, 1287.

21. T. Taskovski and K. Benkhedda, Anal. Chim. Acta, 2002, 453, 143.

22. R. E. Sturgeon. S. S. Berman, and S. N. Willie, Talanta, 1982, 29, 167.

23. L. Elci, M. Soylak, and M. Dogan, Fresenius J. Anal. Chem., 1992, 342, 175.

24. M. Kumar, D. P. S. Rathore, and A. K. Singh, Talanta, 2000, 51, 1187.

25. M. A. Marshall and H. A. Mottola, Anal. Chem., 1985, 57, 729.
26. K. E. Jarvis, J. G. Williams, E. Alcantara, and J. D. Wills, J. Anal. At. Spectrom., 1996, 11, 917.

27. P. Liang, Y. Qin, B. Hu, and T. Peng, Anal. Chim. Acta, 2001, 440, 207.

28. M. Yaman, J. Anal. At. Spectrom., 1999, 14, 275.

29. S. Z. M. Mobarekeh, M. A. Taher, and A. Mostafavi, Can. J. Anal. Sci. Spectrosc., 2005, 50, 7.

30. M. A. Taher, A. Mostafavi, and S. Z. M. Mobarekeh, Asian J. Chem., 2005, 33, 1456.

31. A. Safavi, N. Iranpour, N. Saghir, and S. Momeni, Anal. Chim. Acta, 2006, 569, 139.

32. A. I. Vogel, "Text Book of Quantitative Chemical Analysis", 6th ed., 2000, Longmans, London.

33. L. Yan-Hui, D. Jun, L. Zechao, Z. Yuefeng, X. Cailu, W. Dehai, and W. Bingqing, Carbon, 2003, 41, 2787. 